\title{
ROLES ILUSORIOS E IDENTIDAD CORAL EN EL DRAMA SATÍRICO DEL SIGLO V A.C.
}

\author{
Illusory roles and choral identity in Satyr Drama in the Fifth Century b. C.
}

\author{
Guillermo De Santis* \\ Universidad Nacional de Córdoba-CONICET \\ guillermode.santis@gmail.com / guillermo.de.santis@unc.edu.ar
}

\section{Palabras clave \\ ilusión; \\ rol coral; \\ identidad coral; \\ metateatralidad; \\ drama satírico}

\section{Resumen}

El presente trabajo analiza cuatro escenas de dramas satíricos pertenecientes a Esquilo, Sófocles y Eurípides en las que el Coro de sátiros y Sileno se permiten pensarse a sí mismos en roles distintos a los dispuestos en la trama de las obras. Esta reflexión acerca de los posibles roles corales se da en el contexto de un ensimismamiento que tiende a suspender la acción coral para proyectar una imagen que el auditorio reconoce como imposible e, incluso, contraria a la de un Coro de sátiros no solo en este género dramático sino también en el mito y el imaginario cultural.

Esta contradicción genera un cuadro irrisorio tanto porque los sátiros afirman ser lo que el público sabe que no son y porque el quebranto (¿abrupto final?) de su falsa ilusión y la consecuente vuelta a su rol coral los muestra incapaces de sostener su propia ficción. Al mismo tiempo, estos fugaces momentos son instancias metateatrales que muestran la plasticidad de un Coro capaz de asumir diferentes identidades a pesar de ser siempre un Coro de sátiros y lo ubica consistentemente en el rito teatral y lo contrapone a los coros de la trilogía trágica precedente.

\begin{abstract}
This paper analyzes four scenes from satirical dramas belonging to Aeschylus, Sophocles and Euripides in which the Chorus of Satyrs and Silenus allow themselves to imagine themselves in roles other than those arranged in the plot of the plays. This thought on possible choral roles occurs in the context of self-absorption and tends to suspend the choral action to project an image that the audience recognizes as impossible and, even contradictory to that of a Chorus of Satyrs, not only in this dramatic genre but also in myth and cultural imagery.

This contradiction is a source of laughter both because the satyrs claim to be what the public knows they are not and because the abrupt ending of their self-delusion and the ensuing return to their choral role show them incapable of sustaining their own self-made fiction.

At the same time, these fleeting moments are meta-theatrical instances that speak of the plasticity of a Chorus capable of assuming different identities, despite always being a Chorus of satyrs. This attribute consistently places the Chorus in the theatrical rite in and opposes it to the choruses of the prior Tragic trilogy.
\end{abstract}




\section{Roles ilusorios e identidad coral en el drama satírico del siglo V a.C.}

Uno de los tratamientos más valiosos acerca de la identidad de los sátiros y su posición en el teatro lo ofrece Pierre Voelke (2001), quien propone un análisis profundo de los "aspects figuratifs et configurationnels de du drame satyrique" a partir de las configuraciones imaginarias de los sátiros en la cultura griega de las que el "drama satírico" se vale para el desarrollo de sus tramas. ${ }^{1}$

Voelke (2001) desarrolla la concepción de los sátiros como "figuras intermediarias" en varios sentidos: entre lo humano y lo animal, lo humano y lo divino, lo civilizado y lo incivilizado, entre lo político y lo marginal, entre la niñez y la adultez y entre lo heroico y lo bufonesco. A partir de allí, el drama satírico opera estas figuras en "márgenes" que lo acercan y distancian de forma alternada a los protagonistas heroicos de la tragedia y con los cuales desarrollan la acción satírica.

El análisis de Voelke (2001) deja en claro que los sátiros eluden toda definición taxativa, a excepción de la de seres con una permanente intención de insertarse en espacios que no les son propios (especialmente los de las instituciones de la pólis). ${ }^{2} \mathrm{Y}$, si pensamos estrictamente en Sileno y el Coro de sátiros en la trama de un drama satírico, esta indeterminación condiciona la identidad coral. En efecto, el drama satírico se define por la presencia de un "coro de sátiros", a diferencia del coro trágico que identifica grupos homogéneos e individualizados, como "ancianos de Argos", "jóvenes tebanas" o "suplicantes", por citar algunos casos. Pero este "coro de sátiros”, sin dejar de ser "de sátiros”, asume roles según la trama de la obra, unas veces "esclavos de Polifemo" o "rastreadores de huellas" y, otras veces, "pescadores" o "atletas".

El famoso fragmento del P. Oxy. 1083, ${ }^{3}$ atribuido a Sófocles (Fr. 1130 Radt), demuestra que los sátiros se definen a sí mismos como seres capaces de dominar una amplia gama de saberes que se traducen en posibles “identidades corales" (vv. 6-16):

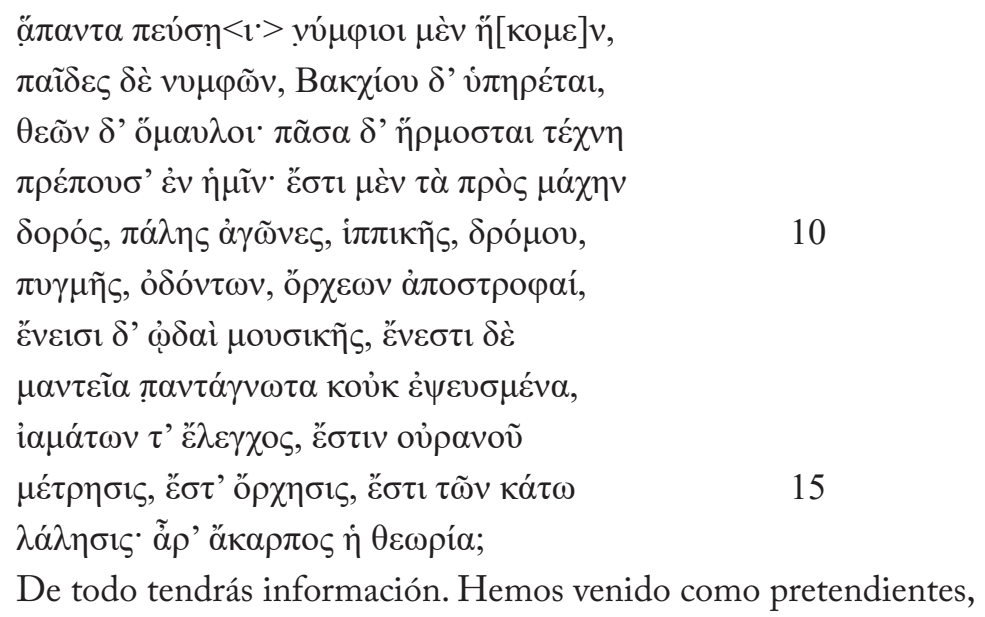

1. Voelke, 2001, p. 377-412.

2. La presencia de los sátiros en la iconografía griega es incontable. Además del thiasos tradicional, las imágenes los muestran en simposios, en ritos, en escenas míticas y en alegorías sexuales de todo tipo. Un tratamiento muy interesante de la presencia de los sátiros en la pólis a través del "humor visual", puede verse en Mitchell (2011, p. 150-234). Sobre la relación de los sátiros y la pólis es siempre atendible el concepto "impoliticità" desarrollado por (Di Marco, 2013, p. 29-51). 3. Sobre la adjudicación del fragmento a una obra satírica de Sófocles, véase Lucas de Dios, 1983, p. 438-440, esp. nota 16. 
hijos somos de ninfas, de Baco servidores

$\mathrm{y}$ de los dioses vecinos. Toda arte adecuada

está ajustada en nosotros. Está lo relativo a la

competición de la lanza, a los certámenes de lucha, de hípica,

de carrera, de pugilato, de dientes, retorcimientos de testículos;

están incluidos los cantos musicales e, igualmente,

los vaticinios del todo desconocidos, y no falseados,

y la prueba de los remedios; está la medición

del cielo, está la danza, está el parloteo de las cosas de abajo,

¿No da frutos la contemplación? ${ }^{4}$

Cada uno de estos saberes, por un lado, indica un posible rol a asumir en la escena, es decir una posible identidad coral, y, por otro lado, es producto de una autopercepción de poder realizar con certeza cualquier tipo de actividad. Hay, sin embargo, una manifiesta distancia entre lo que el coro de sátiros cree ser o pretende asumir y lo que el público tiene en su horizonte de expectativa tanto por su posición en el folclore y el mito, ${ }^{5}$ cuanto por las reglas del género. ${ }^{6}$ Esta distancia entre lo que se es y lo que se pretende ser, constituye, sin dudas, unos de los mecanismos risibles más efectivos.

Un caso particular de esta autopercepción ocurre en pasajes en los que Sileno o los sátiros quedan inmersos en una ilusión errática y ficticia que se contrapone no solo con su imaginario tradicional sino, incluso, con lo esperado por parte de los protagonistas de las obras.

En el reciente volumen de 2019 del Bulletin of the Institute of Classical Studies dedicado al drama satírico de Esquilo, Patrick O' Sullivan expone sus ideas acerca de Arrastradores de redes. ${ }^{7}$ En su análisis de los versos 802-832, en los que los sátiros afirman, de manera errónea pero convencida, que Dánae los desea sexualmente, O’ Sullivan (2019) concluye que es común en el drama satírico de Esquilo un "auto-engaño gracioso" por medio del cual los sátiros creen ser u ocupar un lugar de algo que jamás podrían ser. ${ }^{8}$

Si bien hay diferencias entre los distintos momentos en los que los sátiros (o Sileno como uno de ellos) divagan acerca de su imagen, me propongo analizar algunas escenas en las que observo una ilusión que llamaré "ensimismada", es decir una instancia en la que la ilusión los aísla del diálogo o suspende su comunicación con los actores en la escena. Este momento de ilusión es, a su vez, inmediatamente interrumpida por una intervención que vuelve a los sátiros (o a Sileno) a la trama de la obra, movimiento escénico que refuerza para el público la tensión (jocosa) entre lo que los sátiros son realmente en la escena y lo que creen ser.

4. Salvo indicación específica, las traducciones de los textos griegos me pertenecen.

5. Una idea clara de la posición de los sátiros en el mito, y que está en el horizonte del público, nos lo ofrece Hesíodo en

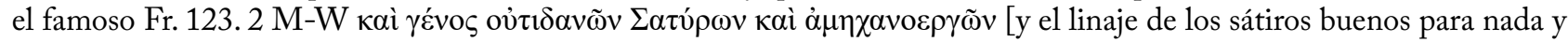
perezosos].

6. Es usual encontrar el Coro de sátiros intentado desarrollar actividades de manera fallida como la de atletas en Emisarios o perros sabuesos en Rastreadores de Sófocles.

7. Me refiero al importante volumen de BICS (2019) editado por Lyndsay Coo y Anna Uhlig.

8. O'Sullivan, 2019, p. 61-62. A los casos de Esquilo añade los de Rastreadores de Sófocles (vv. 154 y ss.) y Cíclope de Eurípides (vv. 179 y ss.). 
El primer caso de análisis es Fr. 240 b atribuido con mucha probabilidad a Prometeo portador del fuego de Esquilo. Este extenso fragmento, aun con muchas lagunas, transmite un posible himno compuesto por una estrofa y una antistrofa, intercaladas por dos estribillos iguales. El tema gira en torno al fuego y el Coro de sátiros imagina una celebración nocturna entre ninfas y pastores. Aquí el fuego no es presentado en su aspecto de elemento central de la técnica y la metalurgia, es decir en su relación con Hefesto, sino, como expone Voelke (2001), en la faz hesiódica de "benefactor" y "nutricio", ligado a la tierra y al hogar familiar. ${ }^{9}$

En la primera estrofa que nos transmite el Fr. 204 b, los sátiros, reconociéndose poseedores del fuego, dicen que serán perseguidos por las Ninfas, afirmación en la que Conrad (1997) señala con acierto la presencia de la inversión de un tópos satírico: las Ninfas persiguen sátiros en lugar del acoso que estos suelen imponer a aquellas: ${ }^{10}$

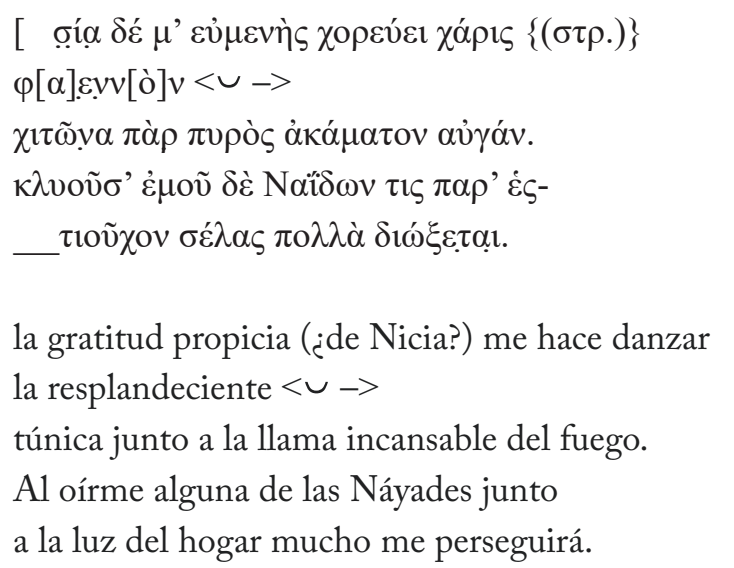

En su ilusión de detentar un poder mediante el fuego, de tener algo que nadie más posee, los sátiros se presentan a sí mismos como objetos de deseo de las Náyades. Su ilusión se hace patente en la metáfora de la cacería amorosa que se actualiza en el verbo $\delta i \omega ́ \xi \varepsilon \tau \alpha .^{11}$

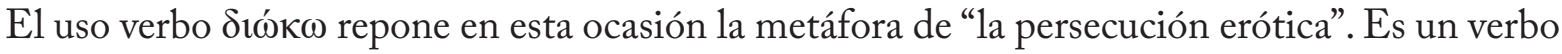
que se ajusta perfectamente al uso de la lengua elevada (poética) en este género y que no es fortuito en boca de los sátiros. Si retomamos algunos ejemplos de Teognis ya analizados por Hualde Pascual

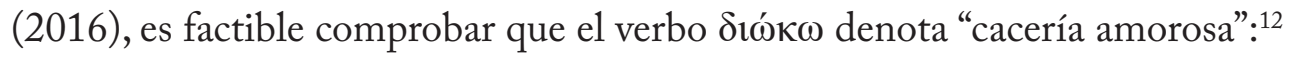

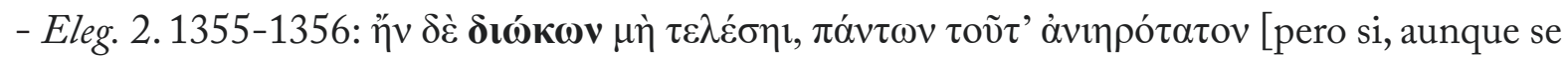
persiga (el amor), no se realiza, esta es la cosa más penosa].

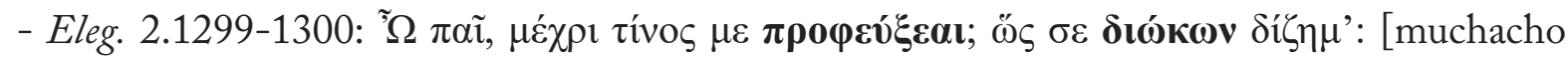
¿hasta dónde vas a huir de mí? Y yo persiguiéndote, cómo te busco...].

9. Voelke, 2001, p. 274-279, esp. p. 276 y n. 4. Voelke sostiene que incluso la descripción del fuego como "llama

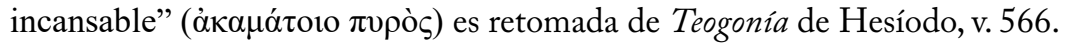

10. Conrad, 1997, p. 88. Antes Gargiulo (1979, p. 85-86), citado por Lucas de Dios (2008, p. 568-569).

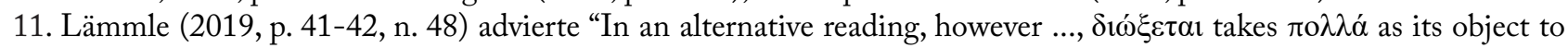

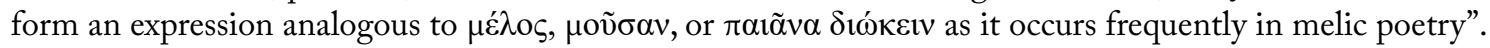

12. Hualde Pascual, 2016, p. 28-30. Las traducciones de los versos teognideos son retomadas del texto de Hualde Pascual. 
Incluso en relación con $\varphi \varepsilon u ́ \gamma \omega:$

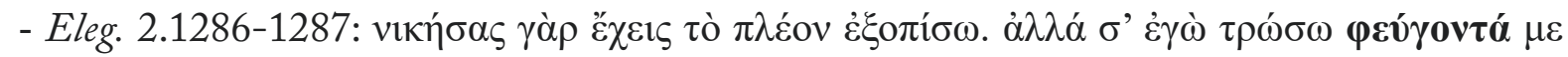
[pues me has vencido, llevas ventaja en adelante; pero yo te heriré cuando me huyas...].

Por otra parte, si los sátiros se valen de una metáfora tradicional de la alta poesía, no respetan, sin embargo, la organización conceptual de dicha metáfora. En efecto, si tomamos la metáfora del amor compuesta a partir del par $\delta \iota \omega ́ \kappa \omega ~ / ~ \varphi \varepsilon v ́ \gamma \omega$, vemos que los sátiros se colocan en posición del "amado / perseguido" de la lírica, generalmente un joven o una doncella, lo que no coincide con su aspecto físico y para el espectador ya es un contraste jocoso. Pero, además, la metáfora de la caza erótica supone que el perseguido escapa de su perseguidor para no conceder su amor o para aumentar el deseo, mientras que los sátiros esperan ansiosos que las Náyades consumen la unión sexual. Los sátiros jamás rehúyen de las ninfas sino que forman parte del cortejo de Dionisio junto a ellas. ${ }^{13}$

Frente a un público que reconoce la vigencia de la metáfora conceptual repuesta por $\delta i \omega ́ \kappa \omega$, los sátiros se autoperciben como un “joven escapando de las Náyades incitadas por Eros”, un rol que se le desconoce no solo en el mito y en la iconografía sino también en la escena satírica. Así, como dije antes, se produce un contraste con la expectativa del espectador, hecho que deja al descubierto la pretensión ilusoria y risible.

Por otra parte, esta ilusión de erómenos se funda sin dudas en el fuego mismo. La asociación del fuego con el amor es tradicional y fácilmente ejemplificable con el famoso poema de Safo 31 Voigt, v.

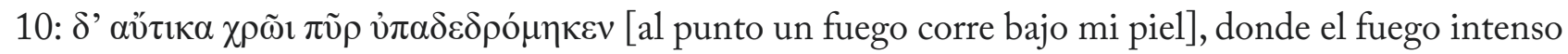
se suma a otros síntomas del amor. ${ }^{14}$

Siendo el fuego un tema central de la trama, no es difícil pensar que los sátiros encuentren en el calor de la llama un nexo sintomático con su apetito sexual. El calor que quema al enamorado, como

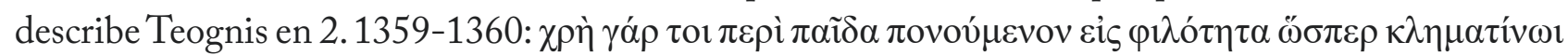

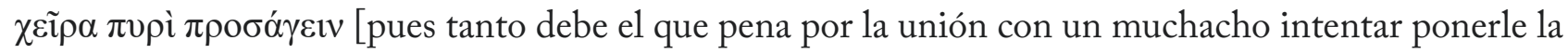
mano encima tanto como debe ponerla sobre fuego de sarmientos...].

En la poesía erótica el amante se quema de pasión. El perseguido, en cambio (es decir, los sátiros en su ilusión), es el que debiera apagar ese fuego amoroso (aquí el deseo de las ninfas) y dar paso a la sensación de "helarse / refrescarse" que manifiesta, en estas metáforas, la consumación del acto sexual. ${ }^{15}$ Por el contrario, en el drama satírico las ninfas y las jóvenes, como Amimona y Dánae, son acosadas violentamente por los sátiros que no consiguen satisfacer su permanente apetito sexual. En este sentido, un contrapunto importante es el Fragmento 686a K de la hipótesis de Sileo de Eurípides:

13. El drama satírico ofrece muchos ejemplos de esta relación de sátiros y ninfas, como en en Rastreadores v. 228, y de la insistencia de los sátiros en frecuentarlas, como en Cíclope vv. 68-69 y 430.

14. Hualde Pascual (2016, passim) recoge numerosos testimonios poéticos.

15. Un caso clarísimo es Safo 48 Voigt. Al respecto, véase Hualde Pascual (2016, p. 35-36). 


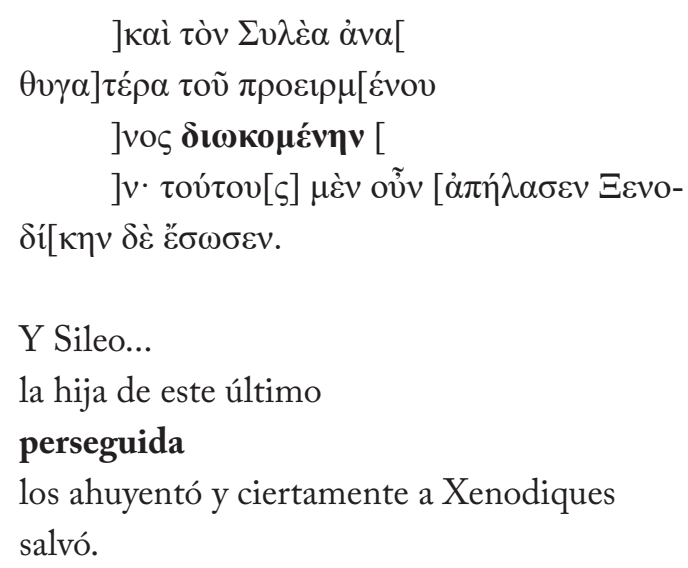

Este fragmento habla de Hercales salvando a Xenodiques (hija de Sileo) de la persecución

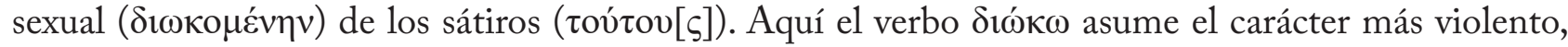
que Voelke define como "une sexualité brute", de la metáfora de la persecución erótica y se ajusta perfectamente a la típica actitud de los sátiros: ellos persiguen para violentar y las jóvenes huyen despavoridas. ${ }^{16}$

En consecuencia, la ilusión de ser ellos mismos objeto de amor encuentra su falta de justificación en una graciosa inversión de roles, si tomamos como parámetro los ejemplos de la lírica y las constantes de la acción de los sátiros en este género dramático. ${ }^{17}$

El segundo caso que analizaré es Rastreadores de Sófocles, donde Sileno se presenta de manera ilusoria como un héroe épico que ha luchado memorables batallas. En esta obra, que retoma el argumento del Himno homérico a Hermes, los sátiros han escuchado el sonido de la lira, hecho que los asustó excesivamente. En Fr. 314 Radt (vv. 145-161) Sileno se lamenta del miedo de sus hijos y más aún de que no hayan heredado su valentía:

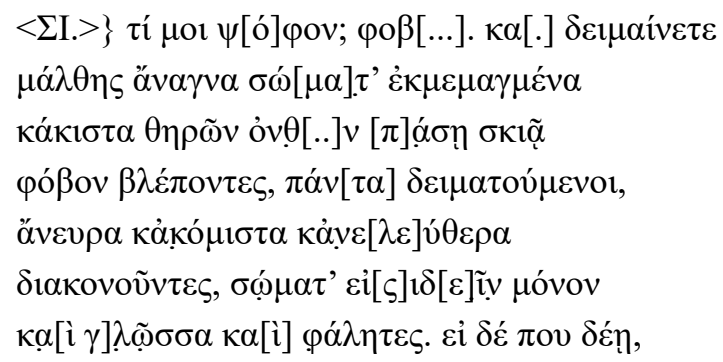

\footnotetext{
16. Véase (Voelke, 2001, p. 214-218) quien incluye esta "sexualidad animal" de los sátiros en el imaginario que los muestra en relación con el falo del asno y ciervos, especialmente p. 214 nota 11. Sobre la trama de la obra de la que daría cuenta este fragmento de la hipótesis, véase (O'Sullivan-Collard, 2013, p. 404-407).

17. Está claro que todo el canto proyecta una situación ideal en la que los sátiros puedan desarrollar su canto y danza, como afirma (Lämmle, 2019, p. 42): "Indeed, the song seems to have dwelled on the description of the thiasotic ideal. Both the very damaged continuation of the text preserved in ${ }^{* *} \mathrm{fr} .204 \mathrm{~b}$ and the other scraps pertaining to the song that are collected under ${ }^{* *}$ fr. $204 \mathrm{c}$ and ${ }^{* *}$ fr. $204 \mathrm{~d}$ adumbrate the temporal and spatial parameters of the projected performance." (la cursiva es mía). Así, incluso en el marco normal del thiasos, los sátiros pueden imaginarse desarrollando un rol que no es el que les corresponde (ser perseguidos por las ninfas) y mostrar su lejanía entre lo que ofrece la khoreía actual y lo que sería la situación ideal.
} 


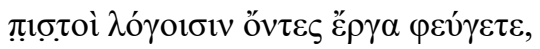

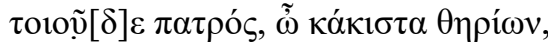

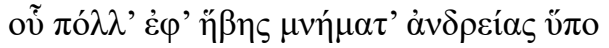

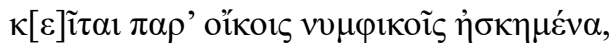

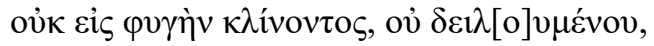

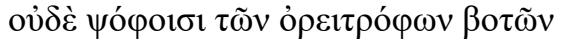

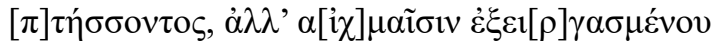

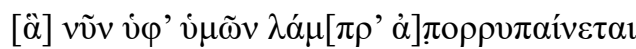

$[\psi]$ ó

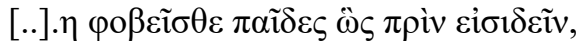

(SILENO).- ¿Por qué de un ruido? [tienen miedo] y se asustan

seres impuros moldeados en cera,

[que son] lo peor de las bestias, porque en toda sombra

ven motivo de miedo y de todo se asustan,

sirviendo sin nervio, sin decoro y en forma impropia de persona libre,

pues no son a la vista otra cosa que cuerpos, lengua y falos.

Y si en algún momento hay una necesidad,

fieles se muestran en las palabras pero rehúyen las acciones,

¡las más viles de las bestias!, fruto de un padre tal

que de su juventud numerosos recuerdos de valentía

quedan realizados en las mansiones de las ninfas.

no por darse a la fuga, o sentir miedo,

ni espantarse por los ruidos de los montaraces animales,

sino por haber llevado a cabo en mil combates las brillantes empresas

que ahora ustedes manchan por causa de un nuevo

y engañoso ruido de pastores en alguna parte,

tienen miedo como niños antes de verlo...

Cito extensamente el pasaje pues Sófocles ha concentrado allí una clara contraposición entre lo que los sátiros "son" en el drama satírico y lo que Sileno pretende ser en su ilusión. Sileno, padre de los sátiros, recrimina duramente a sus hijos y se burla de su cobardía por el miedo frente a un simple ruido que han escuchado, el sonido de la lira recientemente inventada por Hermes.

Entonces, despliega un discurso en el que él mismo se presenta como un héroe épico, como un

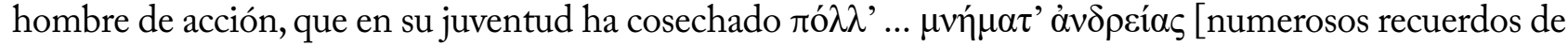
valentía]. El término $\mu v \eta ́ \mu \alpha \tau \alpha$, en su doble valencia de "memorias” y “objetos materiales de la memoria”, hace de las acciones de Sileno un tema digno de poesía épica o de la lírica guerrera y, al mismo tiempo, lo posiciona en la escena como un "objeto que recuerda sus propias hazañas”, en la ilusión de que su sola presencia física evoca combates (antes bien asechanzas amorosas no muy épicas, por cierto). ${ }^{18}$

18. No es la ocasión para explayarse en las consecuencias de mantener en la lectura del pasaje la doble valencia del término, material y abstracta. De hecho las traducciones oscilan entre la materialidad, por ejemplo en (Pozzoli, 2004, p. 217) “i trofei”, antes en Maltese (1982, p. 78), y lo abstracto del recuerdo, por ejemplo (O’Sullivan-Collard, 2013, p. 357) “memorials”. Además, es preciso retomar el uso trágico del término, por ejemplo en Áyax v. 1210 del mismo autor. 
En este pasaje de la obra observamos una puesta en abismo tan sutil como graciosa. En efecto, Sileno habla de sus hijos en términos de lo que el espectador ve: $\sigma \varphi ̣ \mu \alpha \tau ’ ~ \varepsilon i ̀[\varsigma] \delta[\varepsilon]$ ị $\mu$ óvov

$\kappa \alpha[i ̀ \gamma] \lambda \tilde{\varphi} \sigma \sigma \alpha \kappa \alpha[\hat{i}] \varphi \alpha ́ \lambda \eta \tau \varepsilon \varsigma$. El verbo $\varepsilon \dot{i}[\varsigma] 1 \delta[\varepsilon] \tilde{i} v$ es un claro indicador de que la "imagen concreta" de los sátiros es, precisamente, un cuerpo en el que sobresalen la lengua y el falo. ${ }^{19}$ La forma del cuerpo, la charlatanería y el falo son tres de los aspectos más destacables de la opsis del drama satírico y Sileno pretende que su propia imagen se cargue imaginaria y poéticamente de "trabajos dignos de recordar". Esta pretensión imaginaria se sostiene en su discurso por medio de una léxis cuya

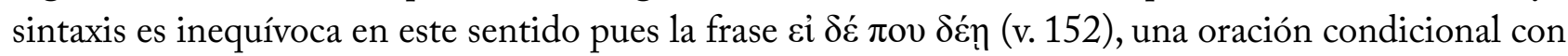
ausencia de ớv más el verbo en subjuntivo, muestra la apelación a la lírica arcaica. ${ }^{20}$

Por otra parte, debe notarse un segundo modelo, nada menos que Siete contra Tebas de Esquilo, v. 498, es decir la tragedia (y una llena de Ares, para contextualizar mejor sus hazañas), a través del

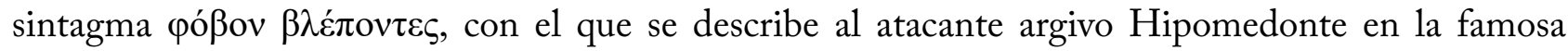
escena de los escudos. ${ }^{21}$

Sin embargo, el modelo es subvertido por Sileno, pues, en la tragedia Hipomendonte "hace visible el temor" para que los tebanos se asusten, mientras que en Rastreadores los sátiros son afectados por el miedo, en un juego de sinestesia de audición y visión, muy rico en el modelo esquileo y que

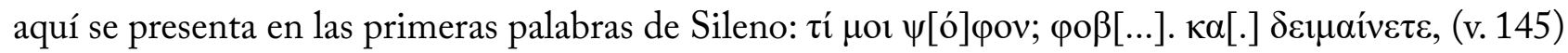
/ póßov $\beta \lambda \varepsilon ́ \pi o v \tau \varepsilon \varsigma$ (v. 148).

En esta obra, la identidad coral de los sátiros es un tema central en tanto asumen físicamente el rol de perros sabuesos en la escena. El pasaje que citamos, entonces, hace foco en aquello los sátiros "siempre" serán en la escena, más allá del rol que les toque jugar: cuerpo, lengua y falo. Efectivamente, es lo que el público observa de manera constante en el drama satírico, y pretender distanciarse de esta "identidad", como se propone Sileno, no hace más que reafirmar su naturaleza.

Así la ficción de ser un héroe de mil hazañas es una ilusión que va en contra de su propia púoıs teatral pues en el drama satírico los "combates" con doncellas y ninfas (Dánae o Amimoma, por ejemplo) no son heroicos sino abusivos, cobardes y fallidos.

Por otra parte, con sus duras palabras Sileno reacciona de manera sorpresiva al bakheuein de los sátiros, es decir a su acción y danza más característica en el mito y en el teatro (Fr. 314 Radt, vv. 132-133):

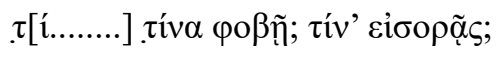

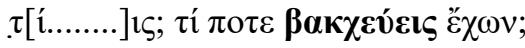

19. Tammaro (2004) propone leer $\sigma \chi \eta \mu \alpha \tau(\alpha)$, sobre la base de Eur. frr. 25,2s. N.2 y 360,26s. N.2, (Erechtheus) con el valor despreciativo de "vana apariencia", o el sentido metatetral de "movimientos" (de danza). Sobre $\sigma \chi \tilde{\eta} \mu \alpha$ como danza y movimiento véase Lawler (1954).

20. Véase Collard, 2013, p. 355.

21."seeing fright': possibly an ironic word-play, for the same Greek words elsewhere mean 'glarin terror' (e.g. the rampaging warrior Hippomedon at Aesch. Seven 498)” (Collard, 2013, p. 355, n. 27). 
¿Por qué ... temes algo? ¿ Qué estás mirando?

¿(...)? ¿por qué danzas manteniendo el paso?

Al rechazar la danza y el canto báquico, Sileno abre la posibilidad de pensarse en otros contextos, como hemos visto antes, y de discutir la presencia de lo dionisíaco en la escena teatral. Se da, en efecto, lo que Lämmle (2019) señala como una tensión entre khoreía y lógos, en la que la permanente referencia al rol coral y la naturaleza dionisíaca del coro se vuelve un debate intradiegético constante. Creo que estas escenas muestran cuán fuerte es la tensión pues al salir de la "trama" en tanto secuencia estricta de sucesos, el ensimismamiento demuestra que los sátiros y Sileno sienten esta tensión, y decirse o ubicarse en situaciones que le son "foráneas", no solo es un mecanismo para extremar la ausencia de lo dionisíaco, sino que su "regreso a la trama" (cuando la ilusión se acaba) es el mecanismo más efectivo para mostrar la condición dionisíaca ineludible de un coro de sátiros. ${ }^{22}$

En este caso la ilusión de Sileno es interferida por el reclamo del Coro que le pide que se una a esta actividad de "sabuesos", es decir que se incluya en esta identidad coral que les toca en suerte desempeñar (Fr. 134 Radt, vv. 169-171):

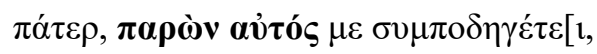

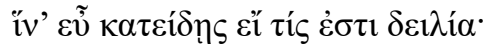

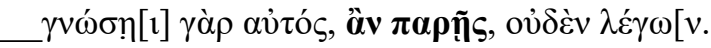

Padre, estando cerca guíame los pasos, para ver bien si es cobardía.

Pues tú mismo verás bien estando presente, que hablas sin sentido.

Los sátiros lo obligan a dejar atrás su ilusoria figura épica y a volver a integrar el coro de la misma manera que la ninfa Cilena recordará que el lugar de los sátiros es el cortejo de Dionisio y no estar al servicio de Apolo en la búsqueda del ganado. ${ }^{23}$

Igualmente, en el prólogo de Cíclope de Eurípides, Sileno, como un aedo, canta las hazañas realizadas como acompañante de Dionisio, primero cuando el dios vagó por el mundo, enloquecido por Hera y, luego, como su ladero en la titanomaquia, guerra mítica en la que él mismo se presenta como un personaje central (vv. 5-9):

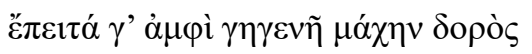

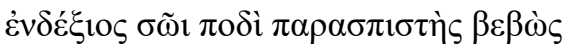

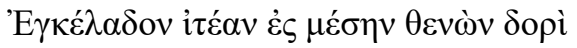

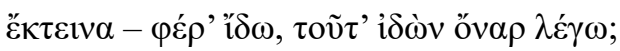

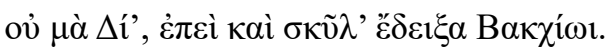

22. Sobre la definición de la khoreia báquica y satírica, véase (Lämmle, 2019, passim).

23. Fr. 134 Radt vv. 221 - 232. Véase Lämmle (2019, p. 34-35). 


\begin{abstract}
Después, durante la lucha con los nacidos de la tierra, cuando, estando a tu diestra armado con mi escudo, maté a Encélado, golpeándole en mitad del escudo con mi lanza. Bueno, vamos a ver, ¿no estaré soñando lo que digo? No, por Zeus, pues estoy seguro de que mostré sus despojos a Baco.
\end{abstract}

El relato de la participación de Sileno en la lucha con los gigantes está enmarcado por dos momentos "reales" de la vida de Dionisio y, en ambos casos, Sileno y los sátiros se mantuvieron fieles a su dios: lo acompañaron cuando, enloquecido por Hera, vagó por el mundo (vv. 3-4) y no lo abandonaron cuando los piratas tirrenos lo raptaron y, en consecuencia, Sileno junto a sus hijos

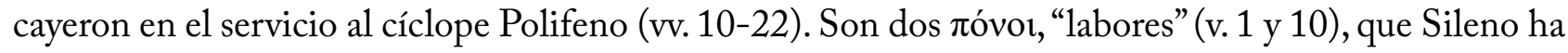
sufrido por fidelidad a su señor. ${ }^{24}$

Entre estos dos sucesos que responden a la tradición mitológica, Eurípides incluye los versos que citamos arriba: Sileno como un hoplita que lucha cuerpo a cuerpo con su señor, enfrenta a Encédalo y lo mata. La mitología atribuye la muerte de este gigante nada menos que a Atenea o a Zeus, de manera que en su ilusión Sileno se coloca a la altura de los vencedores de la Gigantomaquia, un lugar excelso y distinguido en la tradición cultural griega.

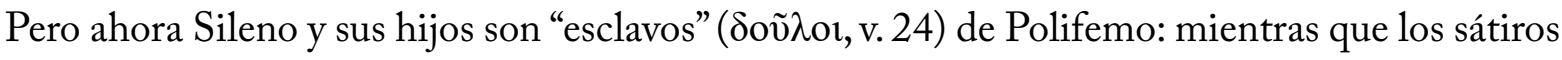
pacen el ganado, él debe barrer, ordenar y mantener limpia la caverna del cíclope.

La trama misma rompe la ilusión que Sileno intentó sostener, cuando en los versos 8 y 9 (cambiando el tono elevado del relato por uno coloquial y reafirmando que no fue su imaginación sino que "realmente" lo vivió) ofrece una intervención intimista que entra en tensión con la continuidad misma del Prólogo, escena que lo tiene a Sileno hablando de la lanza épica pero con un rastrillo en mano (vv. 32-35):

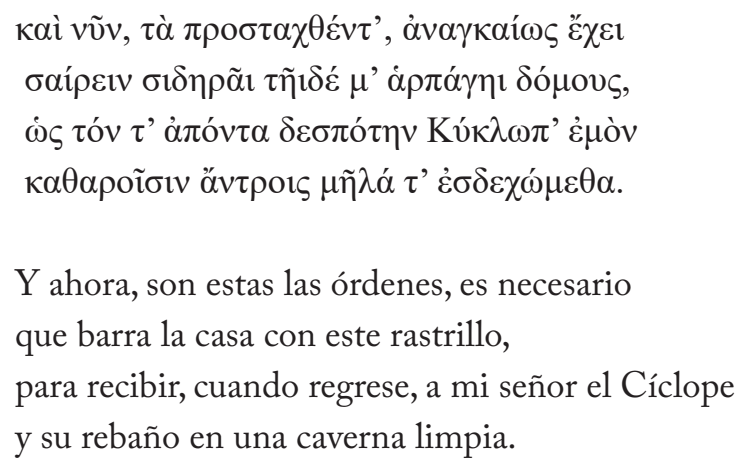

El cambio abrupto no hace sino romper la ilusión y establecer una concordancia entre lo que Sileno y sus sátiros representan, con lo que el público espera y ve.

24. El término y el relato en general pretende establecer una similitud con los más duros trabajos de Heracles, véase Napolitano (2003, p. 97) y Seaford (1984, p. 92). 
En cuanto a Emisarios de Esquilo ${ }^{25}$ los primeros 22 versos del fragmento 78 a col. 1 han sido objeto de una nueva edición textual por parte de Sonnino (2016) quien, de manera brillante, ha identificado los participantes en la escena: Sileno y sus sátiros, por un lado y, por otro, un ódoırópos, “caminante”, piadoso que lleva en sus manos una ofrenda votiva al templo de Poseidón. ${ }^{26}$

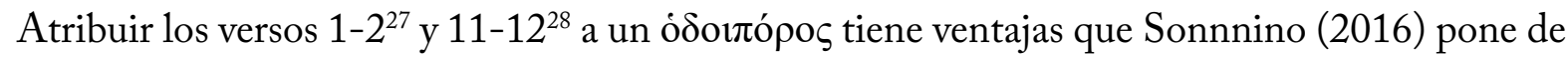
relieve: nada en el texto indica que el hablante de los versos 1-2 salga de la escena, por el contrario, la respuesta de Sileno exige su presencia, escuchando con paciencia las palabras que el sátiro le dedica a las imágenes que ve clavadas en una pared. Reproduzco el texto editado por Sonnino (2016):

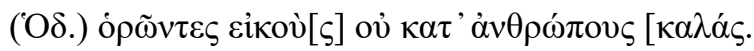

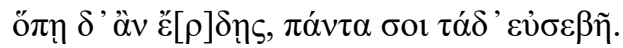

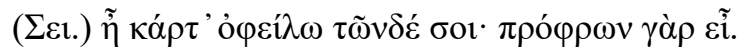

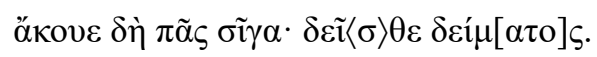

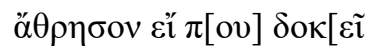

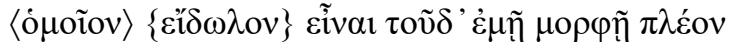

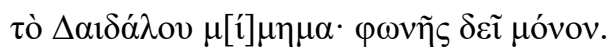

$\tau \delta^{\prime}{ }^{\prime}[\dot{\alpha} \theta \rho] \varepsilon \tilde{\varepsilon}[\varsigma ;$

ö $\alpha \sigma[\hat{0}] \cdot \chi[\omega] \rho \varepsilon[\tilde{i}]$

$\chi \omega \rho \varepsilon \tilde{\imath} \mu \alpha \dot{\lambda} \alpha$.

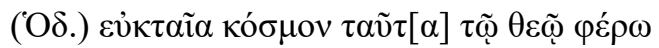

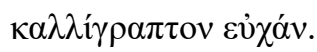

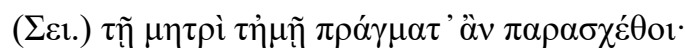

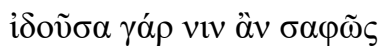

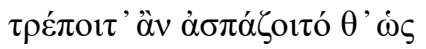

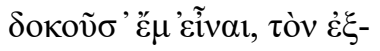

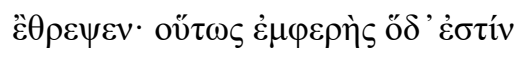

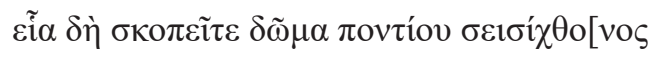

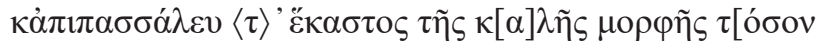

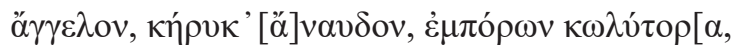

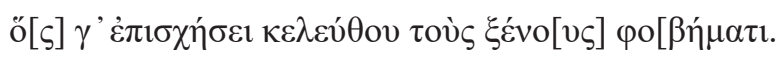

(Caminante): ... cuando veas estatuas de una belleza más allá de lo humano.

Luego, en cuanto cumplas el ritual, todo será piadoso de tu parte.

(Sileno): Te agradezco estas noticas. Eres benevolente.

Silencio completo y escuchad. Necesitáis algo temible.

Considera si esto de aquí,

no es más similar a mi aspecto

que una imitación de Dédalo. Solo necesita hablar.

$\dot{\text { ¿Lo ves? }}$

25. Optamos por esta traducción del título de la obra. Sobre el título Emisarios o Participantes en los juegos ístmicos, véase Lucas de Dios (2008, p. 332-333).

26. Sonnino, 2016, p. 39-60. Una reciente lectura diametralmente opuesta a la de Sonnino, es la ofrecida por Thomas (2019).

27. Estos versos han sido diversamente atribuidos a un "Guardián" del templo de Poseidón y con menos probabilidad a

Dédalo, Hefesto, Teseo, Heracles y Sísifo.

28. Estos versos han sido regularmente atribuidos al Coro (o Semicoro). 


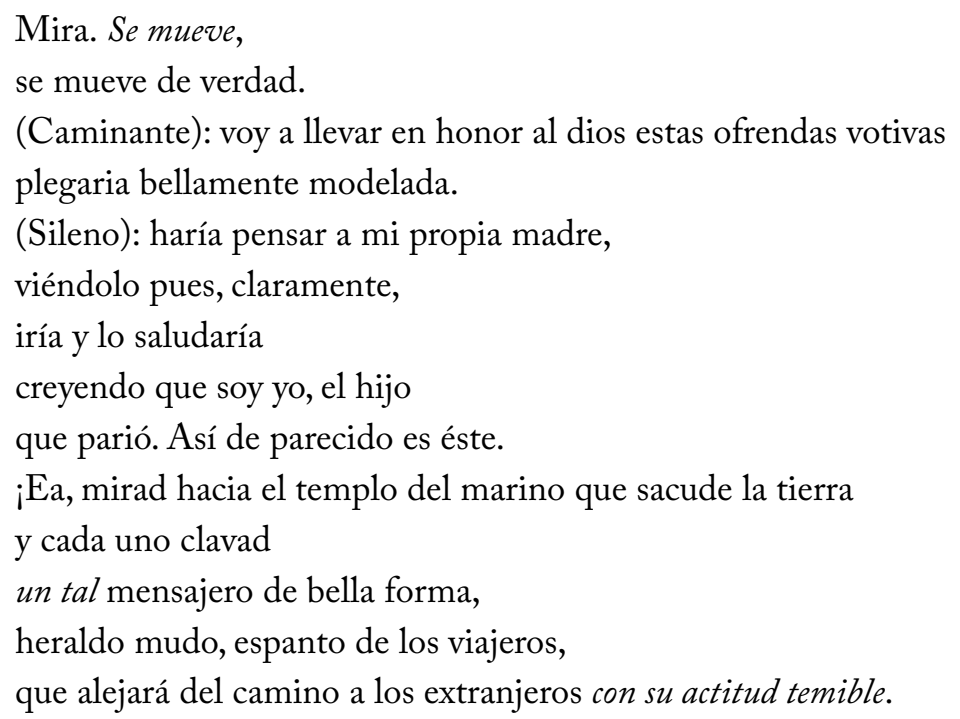

La interpretación general del fragmento que propone Sonnino (2016) se corresponde muy bien con mi análisis. Así, más allá de aceptar su propuesta de que los objetos que se mencionan en el texto no son una máscara de sátiros sino un baskánion, ${ }^{29}$ es su concepción general de la escena lo que considero acertada, a saber: un caminante le indica a Sileno que se halla en las proximidades del templo de Poseidón, lugar que reconocerá cuando vea una serie de estatuas monumentales; allí debe colocar ofrendas votivas como acto ritual. Sileno agradece la noticia y presta atención a un objeto -según Sonnino (2016) un baskánion- que se le asemeja y que el sátiro considera de una factura artístico-mimética excepcional. Ante semejante falta de criterio estético y la exageración de Sileno, el Caminante, que ha escuchado pacientemente, anuncia que se dirigirá hacia el templo de Poseidón y abandona la escena. Sileno, no presta atención ni a las palabras del Caminante ni a su salida, sino que, ensimismado, afirma que el objeto es tan igual a él que su propia madre no lo distinguiría. ${ }^{30}$ Finalmente, Sileno ordena a sus sátiros que levanten la vista hacia el templo de Poseidón y que hacia allí lleven estos objetos que describe como "mensajeros de bella forma que producirán temor".

Esta organización de la escena pone de manifiesto un aspecto central que pretendemos destacar y analizar en este trabajo: Sileno se detiene frente a una figura que se le asemeja (más allá de la identidad de este objeto) y reconoce (o el Caminante le hace saber) que es una imagen que tiene como fin proteger el lugar de cualquier presunto acto de parte de los extranjeros que lleguen para participar de los juegos ístmicos. Así podrían reafirmarlo los términos $\delta \varepsilon^{\prime} \mu[\alpha \tau o] \varsigma$ у $\varphi \circ[\beta \eta ́ \mu \alpha \tau \imath$, en ambos casos conjeturas de Sonnino. ${ }^{31}$

Sileno ve el objeto e inmediatamente afirma que es igual a él y que es de una factura artística elevada y de un realismo imitativo insuperable. Este comentario provoca una suerte de decepción en

29. Sonnino (2016, p. 42-44) realiza un prolijo resumen de las posibles identificaciones de estos objetos que han hecho los estudiosos. Véase también Ferrari (2013).

30. La comicidad del pasaje es bien explicado por Cipolla (2011, p. 206): los sátiros, lejos de ser de bella forma, son tan feos que incluso su madre se espantará de ver objetos iguales a ellos.

31. Véase Sonnino, 2016, p. 42 (aparato crítico) y p. 51-53. 


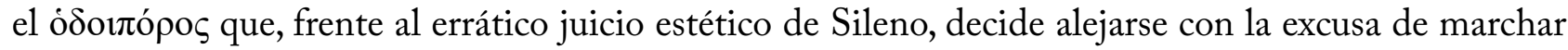
al templo de Poseidón a dejar sus votos. ${ }^{32}$

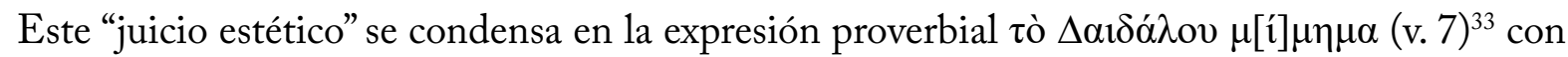
la que Sileno pretende equiparar una figura (en realidad muy inferior en factura, tamaño y veneración)

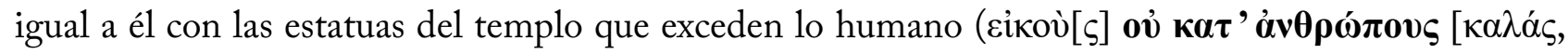

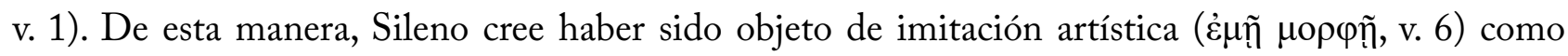
los dioses que guardan el frente del templo de Poseidón. Y, más aún, este objeto no produciría un desequilibrio en el conjunto de las estatuas porque no solo es artístico sino que además es bello como aquellas figuras de los dioses ( $\tau \tilde{\eta} \varsigma \kappa[\alpha] \lambda \tilde{\eta} \varsigma \mu о \rho \varphi \tilde{\eta} \varsigma, ~ v . ~ 19) .{ }^{34}$

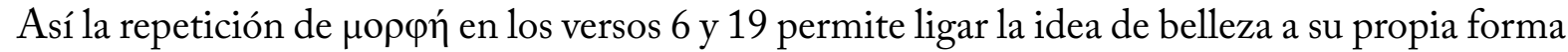
y enmarca de manera general esta escena de ilusión y ensimismamiento. Efectivamente, inmerso en sus consideraciones acerca del valor artístico del objeto que lo imita, Sileno no se percata de las palabras del Caminante ni de su salida de la escena, sino que concentra la atención en la capacidad de este objeto causante de temor, que mantendría alejados a los extranjeros, especialmente a Dionisio que viene en su búsqueda.

Precisamente, cuando Dionisio ingresa en la escena en el verso 23 de este Fr. 78 a, rompe todas las ilusiones de Sileno: por un lado, el objeto clavado en las paredes del templo de Poseidón no logró evitar que Dionisio lo encuentre y, por otro, la descripción de la "nueva forma física" de los sátiros que el dios realiza, es decir la ligadura del falo al modo de atletas, constata que su $\mu$ oṕ̣ está exenta de belleza. Es más, si se acepta la propuesta de Sonnino (2016) de que el objeto clavado es un baskánion, figura que comparte con los sátiros una nariz chata, orejas en punta y, sobre todo, un falo prominente, queda disociada de los supuestos modelos en un rasgo esencial, porque estos ahora se sirven de la

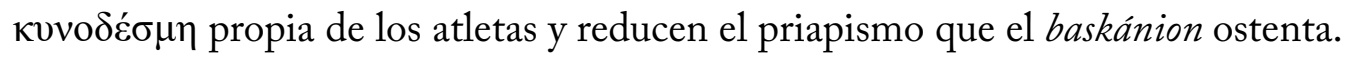

Los cuatro ejemplos que este trabajo presenta muestran la ilusión de los sátiros de imaginarse capaces de encarnar roles fuera de la naturaleza coral y dionisíaca, lo que en términos metateatrales es una interpelación a su rol coral, es decir performativo y escénico.

Esta actitud constante nos dice que el drama satírico como (sub)género dramático insiste en la ficcionalidad y verosimilitud como efectos de una representación dramática y esto implica necesariamente que el público que concurre a presenciar una representación teatral concede al coro dramático la capacidad de asumir distintas identidades. En otras palabras, los sátiros hacen evidente que su espacio "ideal” es el thiasos dionisíaco, pero en la escena se hallan incluidos en una trama mítica y poética que los ubica como Coro en el teatro, espacio en el que pueden asumir diversos roles.

32. En su traducción del pasaje Sonnino (2016, p. 57) agrega, con acierto, la indicación “[ rasseganto]” que debiera marcar la actitud del Caminante ante las palabras de Sileno.

33. Sobre esta expresión proverbial, véase Lucas de Dios (2008, p. 344).

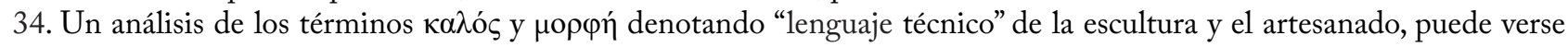
en Stieber (2011, p. 43). 
A su vez, los momentos de ensimismamiento e ilusión dan cuenta de que los sátiros podrían asumir otros roles, que son una doble ficción: primero la de ser sátiros y luego la de ser atletas, modelos de esculturas o guerreros. ${ }^{35}$ Estos momentos de ilusión son una intensa reflexión acerca de la naturaleza de un espectáculo teatral que se basa en convenciones respetadas por autor y espectador, pero que, en el caso del Drama satírico, pone de manifiesto una tensión constante entre la convención de que su coro siempre está compuesto por sátiros y la necesidad de ofrecer variantes que lo alejen de la monotonía. ${ }^{36}$

Kaimio (2001) afirma con certidumbre que las referencias metateatrales a la actividad coral (performativa y ritual) no implican una ruptura de la ilusión dramática. ${ }^{37}$ Las escenas que hemos analizado no reflexionan sobre esta actividad coral, pero advierten que los sátiros se declaran capaces (y conscientes de dicha capacidad) de asumir roles que tensionan la identidad coral concreta en una obra. En tal sentido, es una forma de metateatralidad que revela la plasticidad de un coro y, al mismo tiempo, la imposición del género de hacer que se respete la identidad coral, lo que implica un control de la actividad de los sátiros y su objetivo prioritario del rito dionisíaco.

Finalmente, es preciso remarcar que, siendo el drama satírico (al menos en época de Esquilo) el último drama de la tetralogía, esta particular khoreía, constante y precaria a la vez, contrasta con el Coro de las tragedias que hallan su identidad en la trama del mito (o de la historia) sobre la que el tragediógrafo (que es también satirógrafo), trabaja. Entonces este coro satírico pone de relieve la ficcionalidad del teatro pues son hombres que representan sátiros que están en la escena y, a la vez, ejecutan un rito dionisíaco y que afirman poder cumplir otros roles, una libertad que la performance concreta (la escena y el rito) restringe en función de la trama de la obra.

\section{Referencias bibliográficas}

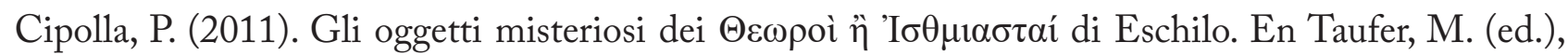
Contributi critici sul testo di Eschilo (pp. 233-245). Tübingen, Narr Francke Attempto Verlag.

Conrad, G. (1997). Der Silen. Wandlungen einer Gestalt des griechischen Satyrspiels. Trier, Wissenschaftlicher Verlag Trier.

Di Marco, M. (2013). Sull' impoliticità dei satiri: il dramma satiresco e la polis. En Satyriká. Studi sul dramma satiresco (pp. 29-51). Lecce, Pensa Multimedia Editore.

Ferrari, F. (2013). Oggetti non identificati: riflessioni sui Theoroi di Eschilo. En Bastianini, G. y Casanova, A. (eds.), I papiri di Eschilo e di Sofocle Atti del Convegno Internazionale di Studi Firenze, 14-15 giugno 2012 (pp. 199-216). Firenze, Firenze University Press.

35. "The satyrs project their choreia into an ideal, or rather idealized, past or into a promising future. 'Ideal', in this case, means 'in the mythical Dionysiac thiasos', 'not in alien myths', 'not on the stage"' (Lämmle, 2019, p. 43).

36. Thomas (2019, p. 74) dice: "A play called Theoroi, in which the satyrs escape training for a Dionysia only to participate in another sanctuary, surely caused many in the audience to reflect on their own theoric participation as spectators at the Athenian Dionysia”.

37. Kaimio (2001, p. 35-38). 
Hualde Pascual, P. (2016). Metáforas del amor en la poesía de la Grecia antigua (I): la épica y la lírica arcaicas. $C F C(g)$ : Estudios griegos e indoeuropeos, 26, 17-47.

Kaimio, M. et alii. (2001). Metatheatricality in the Greek Satyr-Play. Arctos, 35, 35-78.

Lämmle, R. (2019). Precarious Choreia in Satyr Play. BICS, 62, 29-48.

Lawler, L. (1954). Phora, Schêma, Deixis in the Greek Dance. TAPhA, 85, 148-158.

Lucas de Dios, J. (1983). Sófocles. Fragmentos. Madrid, Gredos.

Lucas de Dios, J. (2008). Esquilo. Fragmentos. Madrid, Gredos.

Maltese, E. (1982). Ichneutae: introduzione, testo critico, interpretazione e commento. Firenze, Gonelli.

Mitchell, A. (2011). Greek Vase-Painting and the Origins of Visual Humor. Cambridge, Cambridge University Press.

Napolitano, M. (2003). Euripide. Ciclope. Venezia, Marsilio Editore.

O'Sullivan, P. y Collard, Ch. (2013). Euripides' Cyclops and the Major Fragments of Greek Satyric Drama. Oxford, Aris \& Philips Classical Texts, Oxbow Books.

O’ Sullivan, P. (2019). Aeschylus' Dictyoulkoi: A typically atypical Satyr play? BICS, 62, 49-65.

Pozzoli, O. (2004). Eschilo, Sofocle, Euripide. Drammi Satireschi. Milano, BUR.

Seaford, R. (1984). Euripides: Cyclops. Oxford, Oxford University Press.

Sonnino, M. (2016). Rifugiarsi nel Santuario di Poseidone: note ai Theoroi di Eschilo (P. Oxy. 2162, Fr. I A. Col. I. 1-22 = Aesch. Fr. 78 a, vv. 1 - 22 R.). ZPE, 200, 39-60.

Stieber, M. (2011). Euripides and the Language of craft. Leiden, Brill.

Tammaro, V. (2004). Soph. Ichn. 150. Eikasmós, 15, 57-58.

Thomas, O. (2019). Representatios and Novelty in Aeschylus' Theoroi. BICS, 62, 67-79.

Tragicorum Graecorum Fragmenta vol. 4. Sophocles. Radt. S. (ed.) (1977). Göttingen, Vandenhoeck \& Ruprecht.

Tragicorum Graecorum Fragmenta vol. 3. Aeschylus. Radt. S. (ed.) (1985). Göttingen, Vandenhoeck \& Ruprecht.

Tragicorum Graecorum Fragmenta vol. 5. Euripides. Pars Prior. Kannicht, R. (ed.) (2004). Göttingen, Vandenhoeck \& Ruprecht. 
*Guillermo De Santis es Doctor en Letras Clásicas y Profesor de Historia de la Literatura Griega (Universidad Nacional de Córdoba) e Investigador Independiente de Conicet. Su principal campo de trabajo es el estudio del drama antiguo, especialmente tragedia y drama satírico. Se dedica también al estudio de la poesía épica latina, especialmente Virgilio, y la didáctica de las lenguas clásicas. Coordina el Programa de Estudios Clásicos en el Centro de Estudios de la Cultura y la Sociedad (ConicetUNCórdoba).

RECIBIDO: $15 / 05 / 2021$

ACEPTADO: 05/06/2021 